\title{
РЕАБІЛІТАЦІЙНІ ПІДХОДИ ПРИ ПАРЕЗІ ВЕРХНЬОЇ КІНЦІВКИ У ПАЦІЕНТІВ ПІСЛЯ ІНСУЛЬТУ
}

\author{
Н. Т. Вавринчук, Т. Г. Бакалюк \\ Тернопільський національний медичний університет \\ імені І. Я. Горбачевського МОЗ України
}

У статті проведено аналіз основних реабілітаційних підходів, які застосовують при парезі верхньої кінцівки після інсульту. Використання технологій фізичної та реабілітаційної медицини має грунтуватися на результатах якісних рандомізованих контрольованих клінічних досліджень, які $є$ основою для розробки клінічних рекомендацій.

\section{REHABILITATION APPROACHES FOR UPPER LIMB PARASIS IN PATIENTS AFTER STROKE}

\author{
N. T. Vavrynchuk, T. G. Bakalyuk
}

\section{Horbachevsky Ternopil National Medical University}

The article analyzes the main rehabilitation approaches used in patients with paresis of the upper extremity after stroke. The use of physical and rehabilitation medicine technologies should be based on the results of qualitative randomized controlled clinical trials, which are the basis for the development of clinical guidelines.

Вступ. Інсульт - одна з основних причин захворюваності, інвалідизації та смертності в усьому світі. За даними Всесвітньої організації охорони здоров'я (ВОО3), у світі щорічно реєструють понад 17 млн мозкових інсультів. Інсульт $\epsilon$ провідною причиною не тільки смертності, але й інвалідизації населення планети. Близько 25 \% інвалідизації дорослого населення зумовлено інсультом. Щорічно з'являється понад 6 млн хворих зі стійкими наслідками мозкових катастроф. Більшість пацієнтів, які перенесли інсульт і вижили, стають неповносправними, а 20-25 \% 3 них до кінця життя потребують сторонньої допомоги в повсякденному житті. Така невтішна ситуація спонукала ВООЗ ще в 2006 р. визначити інсульт як глобальну епідемію, що становить загрозу здоров'ю та якості життя населення планети [6].

Метою реабілітації є зменшення кількості ускладнень інсульту, досягнення повного або часткового відновлення втрачених неврологічних функцій, максимальної здатності хворого вести нормальний спосіб життя [1].

У осіб, які перенесли інсульт, частим ускладненням $є$ парез верхньої кінцівки. Пацієнти стають (c) Н. Т. Вавринчук, Т. Г. Бакалюк, 2021 непрацездатними, таким чином рівень їх життя значно знижується. Люди, у яких парез кінцівки, також стикаються з проблемою самообслуговування. Фізичної терапії та ерготерапії, за допомогою якої відбувається відновлення функціонального стану опорно-рухового апарату, інколи буває недостатньо для повного відновлення втрачених функцій ураженої кінцівки.

Основна частина. Відповідно до проведеного аналізу наукових джерел, основними реабілітаційними стратегіями $є$ активація іпсілатеральної моторної кори, інгібування контрлатеральної моторної кори і модуляція сенсорних аферентів. Потім пропонується модуляція сенсорних аферентів: дистальна шкірна електростимуляція, анестезія здорової кінцівки, дзеркальна терапія, віртуальна реальність. Посилення реабілітаційної допомоги означає збільшення загальної кількості годин реабілітації для паретичної кінцівки (пропріоцептивна стимуляція і повторювані рухи) [10].

Дослідження [4] показало, що дзеркальна терапія для пацієнтів з інсультом $\epsilon$ ефективною для поліпшення рухової функції верхніх кінцівок та повсякденної діяльності. Методика реалізована за допомогою 
пристрою розпізнавання жестів (РЖ), були представлені різні завдання.

Результати цього дослідження свідчать про те, що дзеркальна терапія апаратом розпізнавання жестів позитивно впливає на рухову функцію верхніх кінцівок та якість життя пацієнтів із хронічним інсультом. Виявлено, що дзеркальна терапія викликає менший дискомфорт у шиї. Дзеркальна терапія РЖ має набагато більше рухових процесів із використанням зап'ястя та кисті, ніж у звичайній дзеркальній терапії [4].

Нещодавні дослідження показали, що екстракорпоральна ударно-хвильова терапія $\epsilon$ безпечним, неінвазивним, альтернативним лікуванням спастичності [9]. Результати дослідження свідчать про те, що променева екстракорпоральна ударно-хвильова терапія може бути цінним методом для зниження спастичності згиначів кисті та зап'ястя з супроводжуючим покращенням функції кисті та контролю зап'ястя у пацієнтів із хронічним інсультом. Крім того, повторні сеанси променевої екстракорпоральної ударно-хвильової терапії приводять до більш тривалого та помітного ефекту і необхідні для поліпшення функціональної моторності [9].

Також $є$ дослідження застосування робототерапії в реабілітації людей після інсульту [3], що сприяє покращенню функції руки при повсякденній діяльності. Реабілітація за допомогою роботів була настільки ж ефективною, як і фізіотерапія, специфічна для рук, для зменшення порушень руки (оцінювання рухів верхньої кінцівки за шкалою Фугля - Мейєра) в осіб після інсульту, але вона була більш ефективною для вдосконалення стратегій управління рухами, прийнятих під час нетренованого завдання, яке включало вертикальні рухи, які не практикувалися під час тренування. Зокрема, робототерапія викликала поліпшення координації плечей/ліктів та зменшення аномальних сагітальних рухів тулуба [3].

3 фізіотерапевтичних методів у клінічних умовах застосовують електростимуляцію [5] для поліпшення м'язової сили, збільшення обсягу рухів, зменшення набряків та атрофії, загоєння тканин та зменшення болю. Нервово-м'язова електрична стимуляція, яку також називають електричною стимуляцією м'язів, зазвичай забезпечується на більш високих частотах (20-50 Гц), для скорочення м'язів, які можуть бути використані для «функціональних» цілей [5].

Дослідження [5] показують, що високі частоти $\epsilon$ більш комфортними, оскільки реакція сили згладжується і має ефект поколювання, тоді як нижча частота викликає ефект постукування, коли можна розрізнити окремі імпульси. Більш поверхневі електроди активують більше м'язової тканини і розподілятимуть струм на ширшій площині поверхні, зменшуючи щільність струму. Менші електроди будуть концентрувати щільність струму, дозволяючи локальну його концентрацію з меншою ймовірністю стимуляції сусідніх м'язів, але щільний струм збільшує шанс на дискомфорт або біль.

Неінвазивні методи стимуляції мають потенціал для модуляції збудливості кори головного мозку з тривалими ефектами [8]. Збудливість нейронних мереж, розташованих поблизу та віддалено від ушкодженої ділянки, змінюється після інсульту. Отже, застосування неінвазивного методу стимуляції викликає контрлатеральне мимовільне скорочення м'язів; отриманий потенціал, викликаний руховим потенціалом [12], характеризується своєю амплітудою, зв'язаний з кількістю нейронів, які відповіли на стимуляцію. Ця активація може бути збудливою або гальмівною, що призводить до модифікації метаболізму та місцевого кровотоку [8].

При застосуванні транскраніальної магнітної стимуляції використовується електромагнітна індукція як високоефективний безболісний спосіб генерування надпорогового струму в мозку [11]. Лише перша фаза подразника виробляє потік струму з стимуляцією мозку: пригнічений зворотний струм не викликає стимуляції нейронів [13]. Крім того, також спостерігали значне зменшення спастичності як у верхніх м'язах, так і в м'язах кінцівок [11].

На сьогодні кріотерапія $є$ одним з методів, який використовують для тимчасового зменшення спастичності у неврологічних пацієнтів. У дослідженні [7] оцінювали ефективність місцевої кріотерапії у пацієнтів з післяінсультною спастичністю. Встановлено, що локальна кріотерапія в поєднанні з кінезитерапією виявилася більш ефективною при лікуванні спастичності, ніж одна кінезитерапія.

Можливість регулювання м'язового тонусу за допомогою кріотерапії має велике практичне значення. Залежно від інтенсивності та тривалості кріовпливу можна досягти релаксації м'язів або підвищення їх тонусу [2]. Ступінь прояву лікувальних впливів кріотерапії залежить від таких параметрів, як інтенсивність, тривалість, динаміка впливу, площа охолоджувальної поверхні тіла, часовий інтервал між впливами, а також від характеру патології, індивідуальних особливостей і віку пацієнта. Чим 
менший час процедури, тим вища тонізуюча здатність кріотерапії. Більш тривала процедура, навпаки, створює спазмолітичну дію.

Висновки. Реабілітація може стимулювати відновлення верхньої кінцівки як на рівні ушкодження, так і на функціональному рівні, з огляду на суб'єктивну оцінку, відновлювати можливість залучення руки у виконання повсякденних завдань.

\section{СПИСОК ЛІТЕРАТУРИ}

1. Андріюк Л. В. Інсульт. Вибрані питання діагностики, ускладнень, лікування, реабілітації : навчальний посібник / Л. В. Андріюк. - Л., 2009. - 64 с.

2. Баранов А. Ю. Криогенная физиотерапия / А. Ю. Баранов // Физиотерапия, бальнеология и реабилитация. 2005. - № 3. - С. 25-28.

3. Carpinella I. Effects of robot therapy on upper body kinematics and arm function in persons post stroke: a pilot randomized controlled trial / I. Carpinella, T. Lencioni, T. Bowman [et al.] // J Neuroeng. Rehabil. - 2020. Vol. 17 (1). - P. 10. Published 2020 Jan 30. doi:10.1186/ s12984-020-0646-1

4. Choi H. S. Mirror Therapy Using Gesture Recognition for Upper Limb Function, Neck Discomfort, and Quality of Life After Chronic Stroke: A Single-Blind Randomized Controlled Trial / H. S. Choi , W. S. Shin , D.H. Bang // Med. Sci. Monit. 2019. - Vol. 25. - P. 3271-3278. Published 2019 May 3. doi:10.12659/MSM.914095

5. Doucet B.M. Neuromuscular electrical stimulation for skeletal muscle function / B. M. Doucet, A. Lam, L. Griffin // Yale J. Biol. Med. - 2012. - Vol. 85 (2). - P. 201-215.

6. Feigin V. L. Anthology of stroke epidemiology in the 20th and 21st centuries: Assessing the past, the present, and envisioning the future / V. L. Feigin // International Journal of Stroke. - 2019. - No. 14 (3). - P. 223-237.

7. Krukowska J. Ocena skuteczności krioterapii miejscowej u osób ze spastycznością po udarze mózgu / J. Krukowska, M. Dalewski, J. Czernicki // Wiad .Lek. - 2014. - Vol. 67 (2 Pt. 1). P. 71-75. Polish. PMID: 25764779.
Для забезпечення позитивного функціонального результату програми реабілітації після інсульту основані на повторюваних тренуваннях, орієнтованих на виконання певних завдань. Цей огляд літератури показує, що вправи на руку і зап'ястя у пацієнтів після інсульту з геміпарезом необхідні для ефективного відновлення організму та максимального пристосування до навколишнього середовища.

8. Kubis N. Non-Invasive Brain Stimulation to Enhance Post-Stroke Recovery. / N. Kubis // Front. Neural. Circuits. 2016. - Vol. 10. - P. 56. Published 2016 Jul 27. doi:10.3389/ fncir.2016.00056.

9. Effect of Radial Shock Wave Therapy on Spasticity of the Upper Limb in Patients With Chronic Stroke: A Prospective, Randomized, Single Blind, Controlled Trial / T. Y. Li, C. Y. Chang, Y. C. Chou [et al.] // Medicine (Baltimore). 2016. Vol. 95 (18). - P. e3544. doi:10.1097/MD.0000000000003544.

10. Rehabilitation of arm function after stroke. Literature review / L. Oujamaa, I. Relave, J. Froger, D. Mottet, J. Y. Pelissier // Ann. Phys. Rehabil. Med. - 2009. - Apr; Vol. 52 (3). P. 269-293. English, French. doi: 10.1016/j.rehab.2008.10.003. Epub 2009 Apr 9. PMID: 19398398.

11. Increasing Number of Therapy Sessions of Repetitive Transcranial Magnetic Stimulation Improves Motor Development by Reducing Muscle Spasticity in Cerebral Palsy Children / B. L. Rajak, M. Gupta, D. Bhatia, A. Mukherjee // Ann. Indian Acad. Neurol. - 2019. - Vol. 22 (3). - P. 302-307. doi:10.4103/aian.AIAN_102_18.

12. Non-invasive electrical and magnetic stimulation of the brain, spinal cord, roots and peripheral nerves: Basic principles and procedures for routine clinical and research application. An updated report from an I.F.C.N. Committee / P. M. Rossini , D. Burke, R. Chen [et al.] // Clin. Neurophysiol. - 2015. - Vol. 126 (6). - P. 1071-1107. doi:10.1016/j.clinph.2015.02.001.

13. Transcranial Magnetic Stimulation as an Intervention Tool to Recover from Language, Swallowing and Attentional Deficits after Stroke: A Systematic Review // Cerebrovasc. Dis. - 2018. - Vol. 46. - P. 176-183. 